\title{
Spiritual Character of Qilu Culture and Inheritance in New Age*
}

\author{
Ke Sun \\ Marxist Teaching Department \\ Shandong University (Weihai) \\ Weihai, China 264200
}

\begin{abstract}
Qilu culture is an important source of Chinese culture and the spirit of the Chinese nation. For thousands of years, it has been condensed into the vigorous spirit of selfimprovement, the patriotic spirit of upholding spirit, the spirit of salvation by the times, the spirit of virtue and benevolence, the spirit of harmony and difference, and the spirit of creation. They are the cultural resources to cultivate the core values of socialism and have important epochal values. In the course of the great rejuvenation of the Chinese nation, to give full play to the value of Qilu culture, we must carry out creative transformation and innovative development on the basis of profound interpretation of its spiritual essence. It should make the inheritance based on reality.
\end{abstract}

Keywords-Qilu culture; spiritual character; inheritance in new age

\section{INTRODUCTION}

Culture is the gene and soul of a nation, reflecting the historical accumulation of a country and a nation, as well as its tenacious vitality and cohesion. Throughout the 5,000year history of development of the Chinese nation, the great national spirit of unity, peace-loving, hard-working and courage, and continuous self-improvement with patriotism as the core has been formed. After the vicissitudes and ups and downs of the Chinese nation, especially after the baptism of the war in modern times, the Chinese nation has stood in the east of the world in the 21 st century and steadily moved towards the road of rejuvenation. Its exuberant vitality undoubtedly comes from its unique national culture and great spiritual character.

Chinese civilization has a long history and has been passed on from one to the next, forming a unique system of moral principles and values. In April 2014, Xi Jinping discussed with teachers and students of Peking University. "Chinese excellent traditional culture has become the gene of the Chinese nation, rooted in the heart of the Chinese people, subtly affected the way of thinking and behavior of the Chinese people." [1] We must draw nutrition from the excellent Chinese culture and provide strong spiritual impetus for cultural self-confidence and national

\footnotetext{
*Projects: The phased achievements of sub-project of Shandong Social Sciences Major Project (No. 2015AZBJ11), Shandong Social Sciences Planning Project (No. 17DHXJ04), China Postdoctoral Science Foundation (No. 2016M602159).
}

rejuvenation. Qilu culture, as the main body and core of Chinese excellent traditional culture, has important epoch value and needs to be inherited and innovated continuously in the new epoch.

\section{QILU CULTURE IS AN IMPORTANT SOURCE OF CHINESE CULTURE}

Qilu culture originates from the land of Qilu, is the general name of Qi culture and Lu culture. And it is the backbone of Chinese civilization. Its basic spirit is consistent with the spirit of the Chinese nation. Qi culture and Lu culture originated from $\mathrm{Qi}$ and $\mathrm{Lu}$. In the historical development, the fusion becomes a cultural whole. The connotation is rich, and the system is complete. It should innovate the inheritance. It manifests the centripetal force, the cohesiveness and the vitality of Chinese nation. And it lays the foundation for the Chinese culture. Throughout the long history, Qilu culture, represented by Confucianism, has steadily stepped out of the regional restrictions in Shandong and become the mainstream of Chinese culture. Thus, it plays an important role in the history of Chinese civilization.

Looking back on history, we can see many giants of Qilu culture. For example, Guan Zhong, the prime minister of Qi Dynasty (Fig. 1), was the representative of Qi culture. And his thought of governing the country with the combination of etiquette and law, agriculture and commerce, and the combination of righteousness and benefit became the basic policy of state administration after the Han Dynasty, which is still of great value for reference today. For example, Confucianism was founded by Confucius. It is the representative of $\mathrm{Lu}$ culture (Fig. 2). Confucianism was admired as "official school" after the Han Dynasty. And the Four Books and Five Classics became the thought classics and behavior guide of the Chinese nation for thousands of years. Confucianism, represented by Confucius and Mencius, with benevolence, virtue and the mean as its core, has promoted the prosperity and unification of the Chinese nation, and has become a gigantic power to govern the country and lead the life. It is in the backbone and basic position in Chinese traditional culture. 


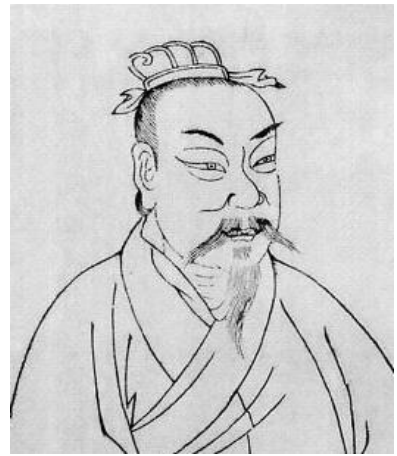

Fig. 1. Guan Zhong, representative of Qi Culture.

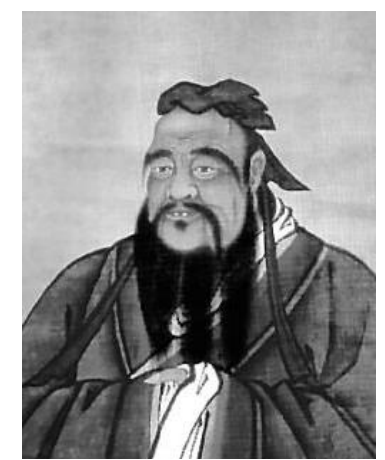

Fig. 2. Confucius, representative of Lu culture.

Qilu culture is a rich mine of culture. It has nourished the people of Qilu for thousands of years and has made indelible contributions to the formation and development of Chinese mainstream culture. Qilu culture is an important source of the formation of the Chinese nation's value concept. Its main body and core position in Chinese culture determines its important role in the cultivation and practice of the socialist core values in China. And it is the source of the selfcultivation of the socialist core values. It can provide useful references for the development of socialism.

Therefore, we need to strengthen the study of Qilu culture, especially its in-depth excavation and inheritance innovation. More importantly, the study of Qilu culture has many important enlightenments and meanings for us to inherit and innovate Chinese traditional culture, to carry forward the core values of socialism, and to promote reform and opening up and socialist modernization. [2]

\section{The SPIRITUAL CHARACTER OF QILU CUlTuRE}

During the Spring and Autumn Period and the Warring States Period, Qi and Lu successively became the important political and cultural centers in the whole country. Confucius, Mencius and Xunzi, Mohism and Soldiers, represented by Mohism and Sun Tzu, emerged with active thought and prosperous culture. For thousands of years, the inheritance and innovation of Qilu culture has finally condensed into such important spiritual character as the vigorous spirit of unceasing self-improvement, the patriotic spirit of upholding integrity, the spirit of salvation through practical application, the moral spirit of benevolent people, the spirit of harmony but difference, the spirit of diligence and wisdom, and so on.

\section{A. The Vigorous Spirit of Self-improvement}

Since ancient times, there are chivalrous men in Qi and Lu. Shandong people pursue that "Heaven is healthy, gentlemen are self-improvement". "The three armies may seize the commander-in-chief, and an ordinary person has his unchangeable ambitions". "It is better to be broken than complete." Continuous self-improvement is the basic spiritual connotation and outstanding character of Qilu culture. It is the endogenous motive force of Qilu people from ancient times to now. For example, Confucianism advocates self-cultivation, family, state administration and peace of the world, which is the embodiment of the spirit of vigorous and enterprising self-improvement.

\section{B. Advocating the Spirit of Patriotism}

Throughout the ages, the Qilu sons and daughters have forged the patriotic spirit of upholding the spirit of Qilu culture. It is the earliest theory of patriotic dialectics in China. Confucius made an argument from three elements: man, family and country. Guan Zhong's thought of patriotism is embodied in his life-long dedication to the prosperity of the Qi Dynasty and his deep feelings for his friends in the interest of the country. Advocating integrity has been recognized and practiced by Shandong people in past dynasties, showing the noble character of patriotism and selfless dedication to the people. Today, we are familiar with Jiao Yulu, and Kong Fansen. In Rongcheng "General County" of Shandong province, there are countless men devoting themselves to new China. It is the embodiment of the patriotic spirit of Qilu culture.

\section{The Spirit of Saving the World}

Being practical is to pay attention to social reality, face social contradictions, and solve social problems with what we have learned. And then, it would achieve the actual effect of governing the country and the people. It embodies the feelings of the Chinese people "taking the whole world as their own responsibility". In the history, many theories and figures emerged in the land of Qilu. Although the ideas and schools are different, the spirit of actively joining and saving the world is the same. Therefore, the basic spirit of Qilu culture is formed. For example, Confucius advocated, "Scholars should be impressive and resolute, and they have a long way to go." The core of Mozi (Fig. 3) is universal love, and the pivot of economizing and worshiping sages is to advocate joining the world. Sun Wu (Fig. 4) summed up the experience of important military struggles in the Spring and Autumn Period and formed "Sun Tzu's Art of War" which spread to later generations. 


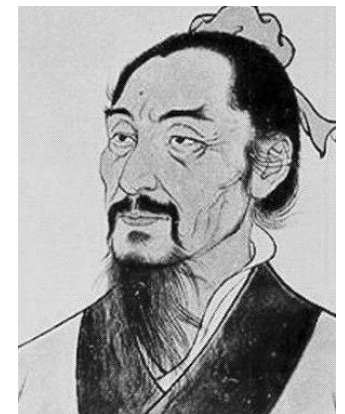

Fig. 3. Mozi represents Mohism

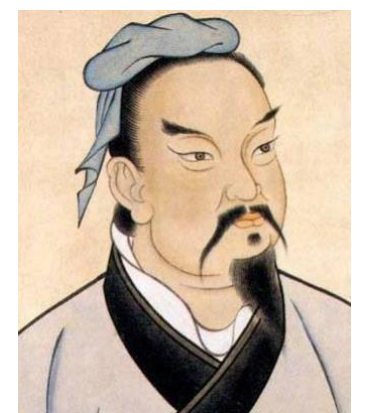

Fig. 4. Sun $\mathrm{Wu}$ is the representative of military strategist in ancient China.

\section{Moral Spirit of Benevolence}

Qilu culture has the value orientation of "the people are valued and benevolent". "Benevolence" is the core of Confucianism, but also the core value of Qilu culture. In the history of Chinese thought, Confucius endowed people with independent historical subject status for the first time. The basic content of the thought system of benevolence is "lover" and "pan-loving people" as Confucius said. Confucianism holds that both good and evil human nature can influence and educate human beings with morality. And it advocates that human beings should practice their social values consciously. The realm of moral freedom can be attained by human nature is benevolence. As the core concept of Confucianism, benevolence is the source of our thought of "governing the country with morality". It has the practicality of deep daily life and the vitality of keeping pace with the age.

\section{E. Harmonious but Different Harmony Spirit}

$\mathrm{Xi}$ Jinping pointed out that good understanding and accommodation, good virtue, and tolerant character of harmony and difference are a kind of cultural concept pursued by Chinese nation. "Harmony but Difference" is the basic condition and rule of the basic law for the common existence of mankind, which pursues the inner harmony and unity, rather than the similarity and consistency on the appearance. "Harmony but Difference" is the basic condition for the common existence of mankind. Qilu culture recognizes differences and antagonisms, advocates tolerance and coexistence. And then, it realizes the harmonious balance between man and man, man and nature on a higher basis, which is a kind of harmony culture. For example, Confucianism advocates "the use of ceremony and precious harmony". "The gentleman is harmonious but different, and the villain is the same but discord." It is the concrete manifestation. The thought of "harmony but difference" in Qilu culture can become the universally accepted values of human society. And then, it would provide the spiritual fertile ground for the construction of the community of human destiny.

\section{F. Diligent and Wise Creativity}

The land of Qilu is rich in resources, culture and talents. The contributions of the cultural and scientific thoughts of the forefathers, such as Guan Zi, Lu Ban, Mo Zi, Bian Que and Jia Sixie, have promoted the development and progress of the society. They have left us a valuable spiritual heritage. Today, after thousands of years, they still shine with wisdom and reflect the creative spirit of diligence and wisdom in the Qilu culture. The diligent and simple Shandong people have inherited the diligent and wise creative spirit of their predecessors and have made outstanding achievements in economic construction and cultural development since the reform and opening up.

\section{INHERITANCE OF QILU CULTURE IN THE NEW ERA}

Today, China has entered a new era of socialist development. Xi Jinping pointed out that nurturing and promoting the core values of socialism must be based on the fine traditional Chinese culture. The Qilu culture in the new era is rooted in profound historical and cultural traditions. It also faces the future and new issues and challenges in the new era. It reflects a dialectical relationship that respects history and inherits development. To carry forward the core values of socialism is inseparable from the inheritance and promotion of Qilu's outstanding traditional culture. At the same time, it must also innovate and develop traditional culture.

\section{A. Inheriting Qilu Culture Needs to Be Integrated into Daily Moral Practice}

The sustainable development and overall progress of China's economy and society have laid a solid foundation for moral construction. Qilu culture (especially Confucian culture) emphasizes the subjectivity of people, adheres to the concept of "reflecting on oneself three times a day", and implements internal moral beliefs in ethical behavior. The practice of morality and the promotion of character in daily life constitute a systematic and effective way of moral practice. In the development period of the new era, some traditional moral cultivation contents and moral practice methods are not applicable to today's society. We need to adjust and inherit and innovate these moral practice methods according to the guiding direction of socialist core values. In particular, the new connotations of Shandong spirit in the new period of reform include innovation, openness, inclusiveness, loyalty and trustworthiness, pragmatism, and hard work. It should be organically integrated into traditional daily moral practices to carry out innovative development of the traditional moral cultivation methods and practices in $\mathrm{Lu}$ culture. 


\section{B. Inheriting Qilu Culture Is Necessary to Be Implemented in Family Tradition and Folk Custom}

As a kind of silent education, the family tradition is the inheritance of the virtues of the Chinese nation. The Qilu style, which is rooted in the land of Qilu and the land of Confucius and Mencius, is an excellent representative of the Chinese national style. Over the past two thousand years, Qilu's family traditions, customs, and folk customs have changed frequently. However, the spirit of poetry and books, filial piety, honesty, morality, morality, self-improvement, innovation, benevolence, and love deeply affects the daily life of Shandong people. At present, the modern value of Qilu tradition etiquette should be fully exploited, especially the integration of Shandong spirit and traditional etiquette and custom in the new period, which will make Shandong spirit externalized in the way of behavior and implementation in life. Under the guidance of the spirit of Shandong in the new period, it is necessary to explore the useful values of Qilu's traditional family traditions, rituals, and festivals. For the new situations and new needs in the process of social development, we must conduct new rituals under the guidance of Shandong spirit in the new period.

\section{Inheriting the Qilu Culture Requires a Complete and Rich Education System}

Education is a social activity with purpose and an organized system for imparting knowledge and technical specifications. Its fundamental value is to cultivate qualified citizens, to create science, knowledge and wealth for the country, the family, and society, and to promote the prosperity of the nation. Education is divided into family education and school education and plays an important role in society. Qilu culture has more systematic traditional education methods. For example, Confucius opened the Xingtan Lecture in the Spring and Autumn Period ("Fig. 5"). According to legend, Confucius has 3,000 disciples and 72 sage, including Yan Hui, Zigong, Zhong You, Zeng Shen, etc.

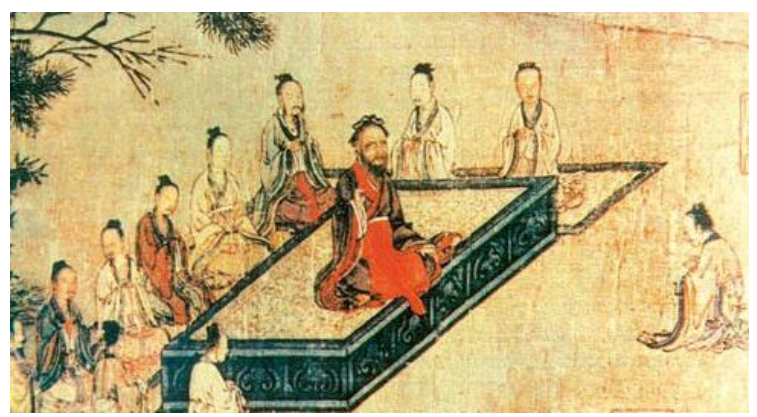

Fig. 5. Ming Wu Bin, "Xingtan Lecture of Confucius".

For thousands of years, the Qilu culture has gradually formed a family education centered on the filial piety of relationships, a school education based on Confucian classics, and a folk lecture based on persuading good virtues to build the Qilu cultural inheritance system in different ways. Different emphasis has been placed on educating different groups of people in society. And the core values and core spirit have been "internalized and externalized".
In the new historical period, we should carry out the transformation and innovation in accordance with the enlightenment resources of the Shandong spirit in the new period. And we should establish the education system of family, school, and society linkage based on the full absorption of the reasonable core of Qilu traditional culture and moral education resources. Then, it would effectively promote the cultivation and practice of the Shandong spirit in the new period.

\section{CONCLUSION}

The state should be the basis. And culture is the soul. The core values of a nation are only deeply rooted in its own rich historical and cultural soil. Combining it with the realistic pursuit and ideal goals of this country and nation, there will be vigorous vitality and endless power support. Today's China has entered a new era of socialist development. The new era must be based on inheriting traditions. And it would have new meteorological and new actions. Qilu culture contains rich and outstanding national spirit character, and has influenced the land and people of Qilu so far. The basic spirit of Qilu culture has become the basic spirit of our nation, and it is of great significance to the rise and revival of the Chinese nation today.

It can be said that the spiritual qualities of Qilu culture are consistent with the social development requirements of the new era and the core values of socialist core values. Qilu culture has been continuous for thousands of years. Since its inception, there has been consistent spirit and changes from time to time. The spirit of Shandong in the new period stems from the great practice of the Shandong people since the reform and opening up. It is also the inheritance and development of Qilu's outstanding cultural traditions for more than two thousand years. The Qilu culture constitutes the profound cultural foundation of the Shandong spirit in the new period and the rich cultural resources for cultivating the Shandong spirit in the new period. We must emphasize creative transformation and innovative development to make it compatible with the realities of social development and promote Qilu culture to a better level. And then, it would serve China's socialist core values.

\section{REFERENCES}

[1] Xi Jinping's talks on excellent Chinese traditional culture: be good at inheriting and innovation. The databases of $\mathrm{Xi}$ Jinping's series of important speech, http://jhsjk.people.cn/article/29075643 习近平谈 中华优秀传统文化: 善于继承才能善于创新, 习近平系列重要讲 话数据库, http://jhsjk.people.cn/article/29075643

[2] Li Junru. The inheritance and innovation of Qilu culture in the study, Guangming Daily, July 06, 2015, 07th edition. 李君如: 齐鲁文化, 在研究中传承和创新, 《光明日报》2015 年07月06日07版。 